\title{
The glyptodont Eleutherocercus solidus from the late Neogene of north-western Argentina: Morphology, chronology, and phylogeny
}

\author{
Alizia Núñez-Blasco, Alfredo E. Zurita, Ángel R. Miño-Boilini, Ricardo A. Bonini, and Francisco \\ Cuadrelli \\ Acta Palaeontologica Polonica 66 (3), 2021: s079-s099 doi:https://doi.org/10.4202/app.00824.2020
}

Glyptodonts (Mammalia, Xenarthra, Glyptodontidae) represent a diversified radiation of large armored herbivores, mainly related to open biomes in South America, with an extensive fossil history since the late Eocene (ca. $33 \mathrm{Ma}$ ) until their extinction in the latest Pleistocene-earliest Holocene. During the Pliocene and Pleistocene, glyptodonts arrived in Central and North America as part of the Great American Biotic Interchange. Within glyptodont diversity, one of the most enigmatic groups (and also one of the least known) are the Doedicurinae, mainly recognized by the enormous Pleistocene Doedicurus, with some specimens reaching ca. two tons. Almost nothing is known about the Neogene evolutionary history of this lineage. Some very complete specimens of the previously scarcely known Eleutherocercus solidus, which in turn becomes the most complete Neogene Doedicurinae, are here described in detail and compared to related taxa. The materials come from the Andalhuala and Corral Quemado formations (north-western Argentina), specifically from stratigraphic levels correlated to the Messinian-Piacenzian interval (latest Miocene-Pliocene). The comparative study and the cladistic analysis support the hypothesis that Doedicurinae forms a well supported monophyletic group, located within a large and diversified clade mostly restricted to southern South America. Within Doedicurinae, the genus Eleutherocercus (E. antiquus + E. solidus) is the sister group of the Pleistocene Doedicurus. Unlike most of the late Neogene and Pleistocene lineages of glyptodonts, doedicurins show along its evolutionary history a latitudinal retraction since the Pleistocene, ending with the giant Doedicurus restricted to the Pampean region of Argentina, southernmost Brazil, and southern Uruguay. This hypothetic relationship between body mass and latitudinal distribution suggests that climate could have played an active role in the evolution of the subfamily.

Key words: Mammalia, Xenarthra, Doedicurinae, anatomy, taxonomy, phylogeny, Pliocene, South America.

Alizia Núñez-Blasco [alizia zgz12@hotmail.com], Alfredo E. Zurita [aezurita74@yahoo.com.ar ], Ángel R. Miño-Boilini [angelmioboilini@yahoo.com.ar], and Francisco 
Cuadrelli [f.cuadrelli@gmail.com], Laboratorio de Evolución de Vertebrados y Ambientes Cenozoicos; Centro de Ecología Aplicada del Litoral (CECOAL-CONICET) Ruta 5, Km 2,5 cc 128 (3400) y Universidad Nacional del Nordeste (UNNE), Corrientes Capital, Argentina. Ricardo A.

Bonini [rbonini@fcnym.unlp.edu.ar], Instituto de investigaciones Arqueológicas y paleontológicas del Cuaternario Pampeano (INCUAPA-CONICET), Facultad de Ciencias Sociales, Universidad Nacional del Centro de la Provincia de Buenos Aires, Olavarría, Argentina. Av. Del Valle 5737, 7400, Olavarría, Buenos Aires, Argentina.

This is an open-access article distributed under the terms of the Creative Commons Attribution License (for details please see creativecommons.org), which permits unrestricted use, distribution, and reproduction in any medium, provided the original author and source are credited.

\footnotetext{
Farif Full text $(2,179.1 \mathrm{kB})$ ।

Far Supplementary file $(168.4 \mathrm{kB})$
} 